ISSN (print): 1698-6180. ISSN (online): 1886-7995

www.ucm.es/info/estratig/journal.htm

Journal of Iberian Geology 36 (2) 2010: 225-242

doi:10.5209/rev_JIGE.2010.v36.n2.9

\title{
Pterosaurs of the Wessex Formation (Early Cretaceous, Barremian) of the Isle of Wight, southern England: a review with new data
}

\author{
Pterosaurios de la Formación Wessex (Cretácico inferior, \\ Barremiense) de la Isla de Wight, sur de Inglaterra: revisión y nuevos \\ hallazgos
}

\author{
S. C. Sweetman, D. M. Martill \\ Palaeobiology Research Group, School of Earth and Environmental Sciences, \\ University of Portsmouth, Portsmouth, PO1 3QL, United Kingdom \\ steven.sweetman@port.ac.uk,david.martill@port.ac.uk
}

Received: 20/11/09 / Accepted: 30/06/10

\begin{abstract}
Micropalaeontological processing of vertebrate-bearing horizons within the Early Cretaceous (Barremian) Wessex Formation of the Isle of Wight, southern England, reveals a rare, but diverse assemblage of pterosaurs. Besides the previously known euornithocheiran Caulkicephalus, the new material demonstrates the presence of three species of istiodactylid, a ctenochasmatid, and a distinct form that cannot easily be placed in a higher taxon. This elevated diversity is in keeping with pterosaur diversity from other Early Cretaceous localities, having some similarities with assemblages from the Early Cretaceous of Brazil, China and Spain. The apparent absence of toothless forms in the Wessex Formation may represent a preservation bias or collecting artefact.
\end{abstract}

Keywords: Pterosauria, Early Cretaceous, Wessex Formation, England, Palaeobiodiversity

Resumen

El análisis micropaleontológico de los niveles estratigráficos ricos en vertebrados del Barremiense (Cretácico Inferior) de la Formación Wessex en la Isla de Wight al sur de Inglaterra, demuestra la presencia de una escasa aunque diversa asociación de pterosaurios. Además del conocido euornitoqueriáceo Caulkicephalus, los nuevos hallazgos han revelado la presencia de tres especies 
pertenecientes a las familias Istiodactylidae, un taxon de Ctenochasmatidae, y un taxón singular de difícil atribución a nivel taxonómico superior. Esta gran diversidad es coherente con la de otras localidades del Cretácico Inferior, y tiene algunas semejanzas con asociaciones del Cretácico Inferior de Brasil, China y España. La aparente ausencia de formas edentadas en la Formación Wessex puede ser debida a un sesgo de conservación o a un artefacto relacionado con la colecta de ejemplares.

Palabras clave: Pterosauria, Cretácico Inferior, Formación Wessex, Inglaterra, Palebiodiversidad.

\section{Introduction}

The Wessex Formation of the Early Cretaceous Wealden Group of the Isle of Wight, southern England (Fig. 1) yields the most diverse Barremian vertebrate assemblages yet recorded. Although dominated by dinosaurs (reviewed by Martill and Naish, 2001), the assemblage includes chondrichthyan and osteichthyan fishes, among which are hybodonts (Patterson, 1966), a neoselachian (Sweetman and Underwood, 2006), amiiforms, semionotiforms and pycnodontiforms (Woodward, 1889). In addition to dinosaurs, the tetrapod assemblage comprises: lissamphibians, including several frogs and salamanders, and an albanerpetontid; perhaps the most diverse lizard assemblage yet recovered from deposits of Early Cretaceous age, including scincomorphs and anguimorphs; rare turtle remains, representing one genus of Pleurosternidae and one of Plesiochelyidae; a diverse assemblage of crocodilians, including members of at least four neosuchian families, Goniopholididae, Pholidosauridae, Atoposauridae and Bernissartiidae, and one eusuchian family incertae sedis, very rare isolated teeth of birds, and mammals, including a gobiconodontid and at least one other eutriconodontan, a spalacolestine spalacotheriid, one (possibly two) multituberculates, at least one dryolestid, a stem boreosphenidan possibly a member of Aegialodontidae, and perhaps more than one other taxon currently represented by milk and indeterminate anterior teeth (Benton and Spencer, 1995; Evans et al., 2004; Sweetman, 2004, 2006a, b, 2007, 2008, 2009a, b). Remains of pterosaurs in the Wessex Formation are however extremely rare and of the few that have been described, only two taxa have been named; the euornithocheiran Caulkicephalus trimicrodon Steel et al., 2005 and Ornithocheirus nobilis Owen, 1870, here, following Howse et al., 2001, considered to be nomen dubium. This apparent low diversity contrasts markedly with Early Cretaceous pterosaur assemblages elsewhere in the world: the approximately coeval Yixian Formation of China has yielded 8 genera (Lü et al., 2006); the Aptian Crato Formation of Brazil has yielded three named genera with two new genera awaiting description (Unwin and Martill, 2007), and the ?early Albian Santana Formation, also of Brazil, has yielded 6 valid genera with two awaiting description (Kellner and Tomida, 2000). Here we re-evaluate the diversity of the Wessex Formation pterosaur assemblage in the light of recent discoveries made during extensive screen-washing for microvertebrates, from a re-examination of material in collections and from information provided by locally based collectors.

\section{History of discovery}

A brief review of the pterosaurs of the Isle of Wight Wealden Group including both the Wessex and Vectis formations, is provided by Howse et al. (2001). Their analysis largely reviews the history of discoveries of pterosaurs from the slightly younger Vectis Formation, a deposit dominated by fresh water and brackish lagoonal sediments that conformably overlies the Wessex Formation (Radley, 1994) (Fig. 2). The Vectis Formation yields the distinctive istiodactylid Istiodactylus latidens (Seeley, 1901) (Hooley 1913, Howse et al., 2001) and a long, slender, gently curved, conical tooth, (MIWG 5318) from the Vectis Formation exposed near Barnes High (Fig. 1) on the south-west coast also indicates the presence of Euornithocheiridae. Recently, four conical teeth, which may also represent an ornithocheirid (IWCMS.2009.471-2) (Fig. 3A and B respectively) have been recovered from a gutter cast in the Shepherd's Chine Member of the Vectis Formation at Yaverland. However, these require further preparation to reveal details of their morphology and all of the Vectis Formation teeth remain undescribed.

The first evidence for pterosaurs in the Wessex Formation was reported by Owen (1870) who described, and named a fragment of long bone (BMNH 36652, 36652a) as Ornithocheirus nobilis (Fig. 4). It was obtained (date unknown) by Gideon Mantell, and remained in his collection until sold to the British Museum of Natural History in 1853. Strangely, Mantell (1854) makes no mention of pterosaur (or bird*) bones from the Isle of Wight in the third edition of his Geological Excursion round the Isle of Wight. Lydekker (1888) lists additional pterosaur material from the Isle of Wight, including a proximal humerus attributed to Ornithocheirus (?) sp. (BMNH R 558) and BMNH R 176 which later became the holotype of Istio-

\footnotetext{
*Mantell held the view that thin-walled, hollow bones from the Wealden Group belonged to birds.
} 


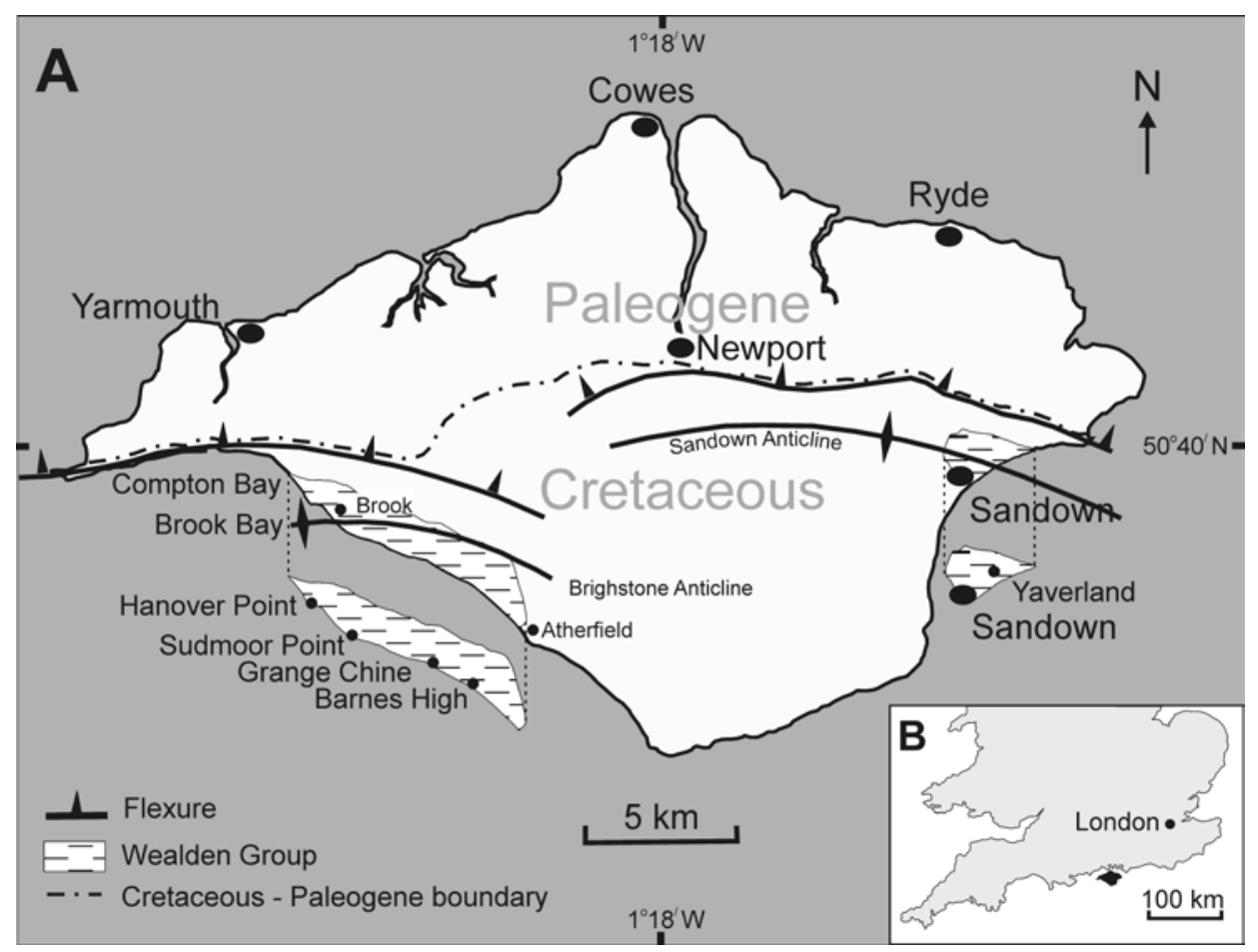

Fig. 1.- A, outline geological map of the Isle of Wight with exposure of the Wessex Formation and pterosaur localities indicated. B, location map.

Fig. 1.- A, mapa geológico esquemático de la Isla de Wight indicando las áreas donde la Formación Wessex aflora y las localidades donde han aparecido los pterosaurios. B,. mapa de localización.

dactylus latidens. This material cannot be satisfactorily assigned to a Wealden Group horizon. Seeley (1901, p. 15, fig. 66) figures a cervical vertebra of 'Ornithodesmus' from the Isle of Wight in his famous Dragons of the Air, and provides a description that satisfies ICZN criteria for validating a taxon (see Howse et al., 2001 for a discussion). Seeley (1901) also notes that the best preserved remains of Wealden pterosaurs were from the Isle of Wight, and had been collected by the reverend William Fox. According to Lydekker (1888), Fox collected the holotype of 'Ornithodesmus' latidens (BMNH R 176), a partial skull and associated postranial remains, from Brook. If this refers to Brook Bay, rather than a wider vicinity, then the specimen is most likely from the Wessex Formation as the Vectis Formation is not present here (see below). The brain case of R 176 was sectioned and briefly described, but not figured, by Newton (1888). A more complete analysis of this specimen and two others (BMNH R 3877 and BMNH R 3878) from the Vectis Formation was provided by Hooley (1913). A pioneering functional analysis of the wrist bones of this taxon was reported by Hankin and Watson (1914), but this was the last time pterosaurs from the Isle of Wight were studied in detail until Green (1995) and Martill et al. (1996) reported on material in the private collection of Mr Mick Green of Brighstone. These authors speculated on the wing span of Wealden pterosaurs on the basis of some large wing bone fragments from the Wessex Formation, and suggested that gigantic pterosaurs were present in the Cretaceous much earlier than had previously been assumed. During the summer of 2002 material referable to the new genus and species Caulkicephalus trimicrodon Steel, Martill and Unwin, 2005, was discovered by school boy, Master Dan Davies, in foreshore exposures of bed 33 of the Wessex Formation (Figs. 1-2) at Yaverland. This material (IWCMS 2002.189.1-2, 4) and its discovery became the subject of a TV programme screened on an independent TV channel (Steel et al., 2005). A tooth accessioned in the collections of the Isle of Wight Museum of Geology (as it then was) in the 1920s and originally identified as a hybodont fin spine (MIWG 2756) has been re-examined by the first author and found to be a tooth of an ornithocheirid. It was collected from the Wessex Formation at Yaverland (Fig. 1) and based on size and cross sectional shape could pertain to Caulkicephalus (Steel et al., 2005) (see below). Most recently, based on an isolated humerus recovered from a variegated clay horizon exposed on the south-west coast of the island, Witton et al. (2009) have recorded an azhdarchoid in the Wessex Formation assemblage.

\section{Material and Methods}

Most of the macro remains discussed here are accessioned in the collections of the Natural History Museum, London (BMNH), the University of Cambridge (CAMZ) or in the collections of the Isle of Wight County Museum Service (MIWG and IWCMS). The latter's most significant Early Cretaceous vertebrate fossils are currently on display at the council-run museum and visitor attrac- 


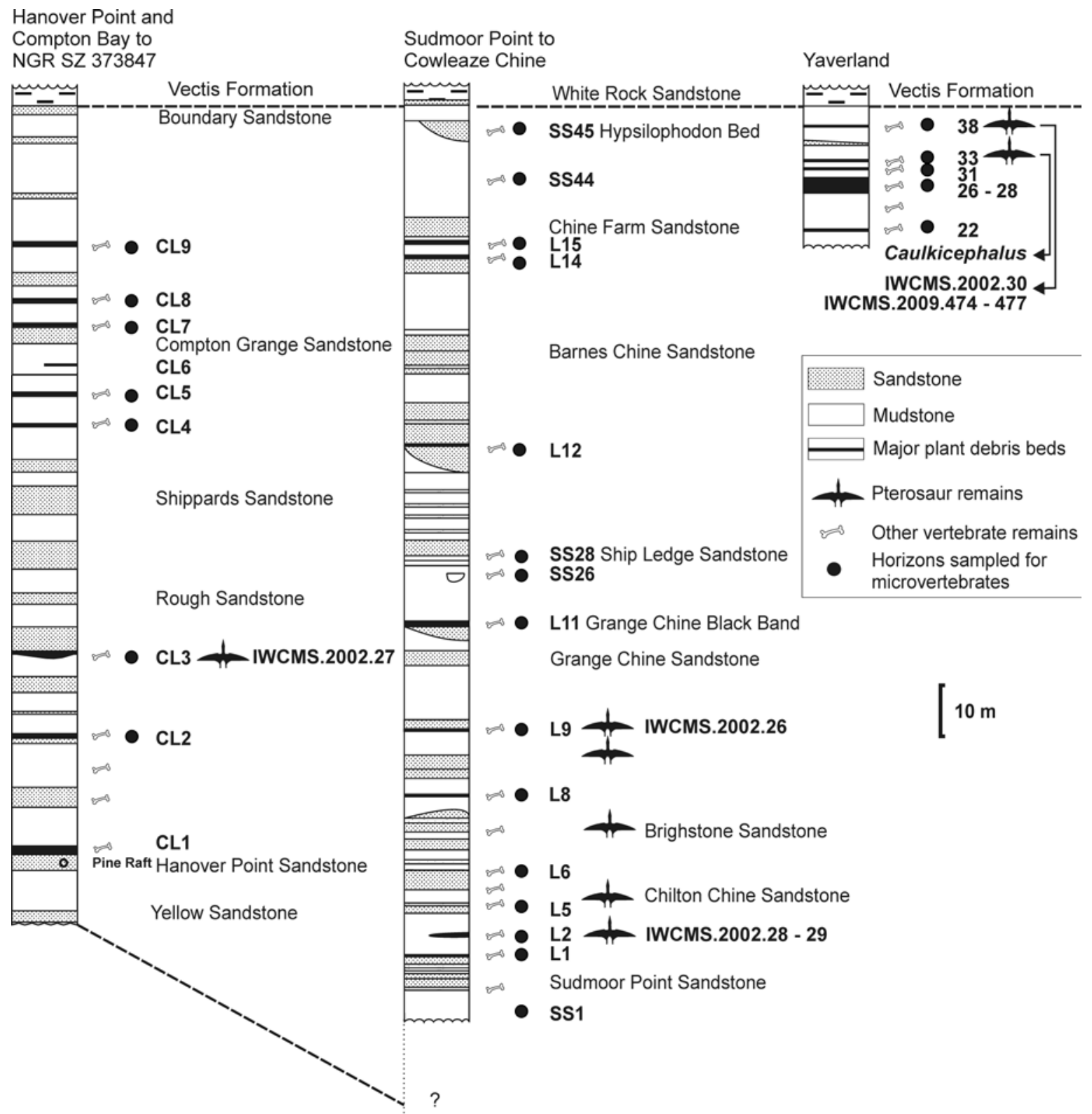

Fig. 2.- Stratigraphic logs for the Early Cretaceous Wessex Formation of the Isle of Wight, southern England. Bed numbers for south-west coast logs follow Stewart, 1978, those for Yaverland follow Radley, 1994.

Fig. 2.- Columnas estratigráficas del Cretácico Inferior de la Formación Wessex en la Isla de Wight, sur de Inglaterra. La numeración de las capas de las columnas de la costa suroeste sigue la de Stewart, 1978. Y la de Yaverland sigue la de Radley, 1994.

tion Dinosaur Isle. This material has been obtained by casual collecting, and many specimens have been picked from the beach, rather than from in situ, over a period of more than 150 years (Martill and Naish, 2001). More recently (2002 to present) screen washing by the first author of distinctive fossiliferous horizons known as plant debris beds (Sweetman and Insole, 2010) has revealed an abundance of microvertebrate remains, including nine pterosaur teeth, and very fragmentary and fragile skeletal remains primarily comprising scraps of long bones. Fragmentary, but surprisingly well preserved pterosaur remains were also observed in a conglomerate associated with the Brighstone Sandstone (Fig. 2). However, these proved impossible to collect due to their fragility and strong cementation of the enclosing matrix. Specimens obtained from bulk screening were isolated from residues using a binocular microscope and images obtained using scanning electron microscopy. Measurements were taken electronically using associated software. In consultation with IWCMS and BMNH it was agreed that the specimens would not be coated in order to aid possible further research. An environmental chamber was not available 


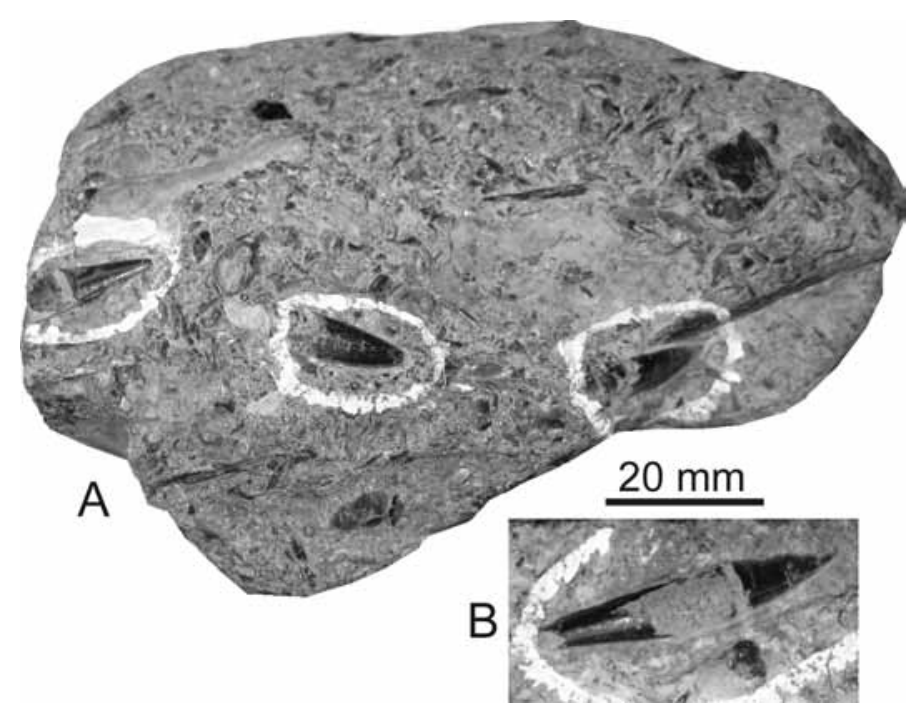

Fig. 3.- A, IWCMS.2009.471. Portion of gutter cast from the Shephards' Chine Member, Vectis Formation, Isle of Wight. Three pterosaur teeth attributable to Ornithocheiridae show current alignment in a coarse sand of fish bones and fine to medium quartz sand. B, IWCMS.2009. 472.

Fig. 3.- A, IWCMS.2009.471. Fragmento de un gutter cast en el Miembro Shepard's Chine de la Formación Vectis, Isla de Wight. Tres dientes de pterosaurio atribuibles a Ornithocheiridae aparecen alineados por la corriente en una matriz formada por arenas gruesas compuestas por fragmentos de huesos de peces y por arena fina a media de cuarzo. B, IWCMS.2009.472.

and images were therefore obtained using an acceleration voltage of $1 \mathrm{KV}$.

\section{Geology and Locality}

The Wessex Formation is a non-marine sequence of mainly fluvial clastic strata that are exposed in the cores of two en-echelon anticlines on the Isle of Wight (Fig. 1). It forms the lowest part of the Wealden Group in the Wessex Basin and palynological, magnetostratigraphic and fossil wood carbon isotope data suggest that the whole of the exposed Wessex Formation on the island is Barremian (Kerth and Hailwood, 1988; Hughes and McDougall, 1990; Robinson and Hesselbo, 2004). It also indicates that the overlying Vectis Formation comprises deposits of late Barremian to early Aptian age and that the HauterivianBarremian boundary lies close to the level of the so called "Pine Raft" (White, 1921) exposed on the foreshore at Hanover Point (National Grid Reference SZ 379837) (Figs. 1-2). Its base is not seen on the Isle of Wight, but borehole evidence shows that here the Wealden Group has a total thickness of about $580 \mathrm{~m}$ and rests on Purbeck Group strata of Berriasian age (Falcon and Kent, 1960). The exposed Wessex Formation on the Isle of Wight is approximately $180 \mathrm{~m}$ in extent (Stewart, 1978). It was deposited in a meander-belt river system with a dominant flow direction from west to east (Stewart, 1978, 1981a, b, 1983). The river system occupied a similar trending, fault bounded basin, the Wessex Basin, which can be traced on land from Dorset to the Isle of Wight, and beyond into northern France and Belgium (Allen, 1998). Exposures of the Wessex Formation are confined to the coast-line of the Isle of Wight at Yaverland in the south-east and between Atherfield and Compton Bay in the south-west (Fig. 1). The formation is only gently folded and some of the sandstones can be traced for hundreds of metres. However, rapid lateral facies changes occur in most argillaceous strata rendering correlation between many exposures on the south-west coast, and between exposures on the south-west and south-east coasts highly problematic. Landslips may obscure some strata but erosion is rapid and exposures are refreshed by frequent winter storms from the south-west.

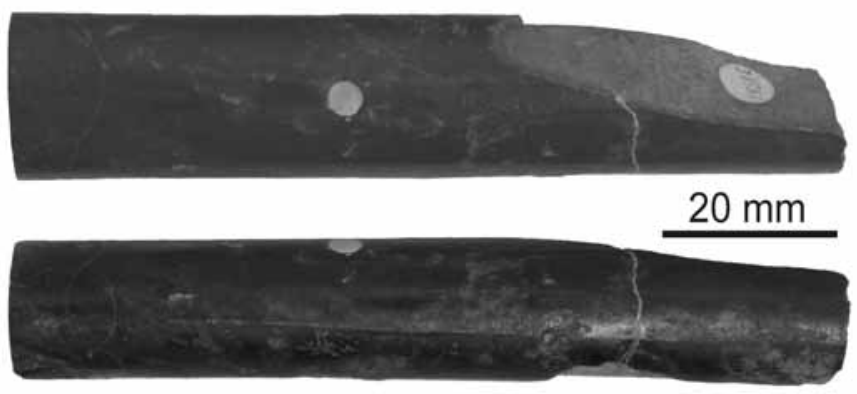

Fig. 4.- Ornithocheirus nobilis Owen, 1870 from an unspecified locality and horizon on the Isle of Wight. BMNH 36552.

Fig. 4.- Ornithocheirus nobilis Owen, 1870 de localidad y horizonte sin especificar de la Isla de Wight. BMNH 36552.

\section{Taphonomy and preservation}

Lithologically the Wessex Formation is dominated by over-bank mudstones of reddish hues, channelised sandstones with caliche conglomerates, variegated clays regarded as palaeosols developed in overbank and lacustrine deposits, and thin, poorly sorted debris flows rich in plant remains called plant debris beds (Stewart, 1978, 1981a, b, 1983; Insole and Hutt, 1994; Radley 1994; Sweetman, 2009b; Sweetman and Insole, 2010). Pterosaur remains have been recorded from all of these lithologies and their preservation reflects the taphonomic and diagenetic pathways associated with the distinctive deposition and burial processes associated with each lithology. Witton et al. (2009) reported a single pterosaur humerus from the variegated clays facies. This is assigned to the Azhdarchoidea and is preserved in 3-D. It is cream/white, and full of microfractures, with minor pre-burial abrasion damage. Cavities within the spongiosa are filled with an ochre- 
coloured clay matrix. By contrast, pterosaur bones from the plant debris beds are black or very dark brown, some show cracking and crushing due to compaction but most are unabraded (see Steel et al., 2005), and have spongiosa cavities filled with white calcite and pyrite. Pterosaur remains from the plant debris beds may be associated, but disarticulated or occur as isolated elements, including teeth and bones. Only isolated bones and teeth occur in the sandstone channel and caliche conglomerate facies. These show a variety of preservational styles ranging in colour from cream to black or dark brown. Most are abraded but very occasionally well preserved material is encountered (SCS pers.obs. 2003). These taphonomic characteristics distinguish Wessex Formation pterosaurs from those found in the Vectis Formation. Here, pterosaurs occur as associated, 3-D skeletons in grey clays and shales, often partly encrusted with diagenetic pyrite and sideritic mudstone, or as isolated elements in gutter casts in concentrates of density sorted bone-sand (Fig. 3).

\section{Systematic palaeontology}

Note: the systematics adopted here follows that of Unwin (2003), but takes into account some minor adjustments provided by Lü et al. (2010).

Pterosauria Kaup, 1834

Breviquartossa Unwin, 2003

Monofenestrata Lü, Unwin, Jin, Liu and Ji, 2010

Pterodactyloidea Pleininger, 1901

Ctenochasmatoidea Unwin, 1995

Ctenochasmatidae Nopcsa, 1928

? Gnathosaurinae Unwin, 1992

A single pterosaur tooth (IWCMS.2002.28) is tentatively referred to Gnathosaurinae on the basis of its long, slender aspect with sub-parallel margins (Fig. 5). It comprises a possibly incomplete crown and was collected from bed L2 at Sudmoor Point on the south-west coast of the island at National Grid Reference SZ 3945182727 (Figs. 1-2). For the purpose of the description it is assumed that the tooth projected laterally from the jaw and that it is from the lower dentition (see affinities section below). It may, of course, be a tooth from the upper dentition, in which case the orientation nomenclature would have to be emended accordingly. The base of the tooth (Fig. 5A-B) is uneven and may represent a broken surface. Matrix fills a basal opening which may be a resorption pit but which is more probably the preserved basal extremity of the pulp cavity. Support for the latter interpretation is found at the apex. Substantial wear here has exten-

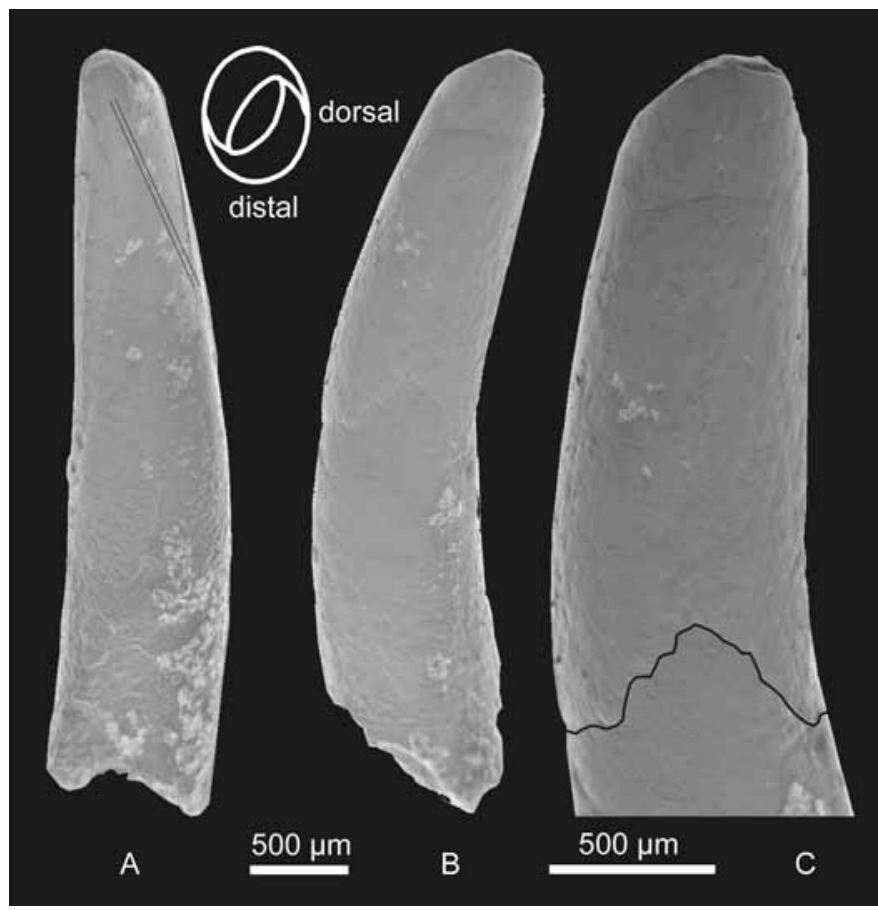

Fig. 5.- Possible gnathosaurine pterosaur tooth from the Wessex Formation of the Isle of Wight. IWCMS.2002.28 in: A, distal view. Fine lines indicate orientation of scratches; B, mesioventral view; $\mathrm{C}$, enlargement of the apex of the crown in mesioventral view showing basal extremity of enamel. Line drawing, top left, to illustrate torsion at the apex of the crown.

Fig. 5.- Posible diente de pterosaurio Gnathosaurinae de la Formación Wessex de la Isla de Wight IWCMS.2002.28. A, vista distal. Las líneas finas indican la orientaciónn de las estriaciones, B, Vista mesioventral; $\mathrm{C}$, detalle del ápex de la corona en vista mesioventral mostrando el extremo basal del esmalte. La línea en la parte superior izquierda ilustra la torsión del ápex de la corona.

ded to reveal a narrow, circular, central opening probably representing the apical extremity of the pulp cavity. The preserved part of the crown is distally recurved with a height of c. $4.2 \mathrm{~mm}$ and a dorsoventral width of $0.9 \mathrm{~mm}$. The base of the tooth is somewhat dorsoventrally compressed and oval in cross-section. The apex of the crown, which is also oval in cross-section, is rotated so that what would have been the distal surface, absent rotation, lies in a dorsal position (line drawing Fig. 5). Enamel covers the apical half of the preserved part of the crown but its basal extent is variable (Fig. 5C). Dorsally the enamel has been breached for $c$. three quarters of the distance from the apex to its basal extremity. The facet is polished and bears a number of fine, parallel, linear scratches lying at an acute angle mesiodorsally to the apicobasal axis of the enamelled part of the crown (Fig 5A). The mesial and distal margins of the enamelled part of the tooth comprise narrow dorsally raised ridges. The ridge on the distal margin is more robust than that on the mesial margin. Wear at the apex and possible breakage at the 
base indicate that the crown may have been significantly higher immediately after eruption.

\section{Affinities}

IWCMS.2002.28 is undoubtedly the tooth of a pterosaur based on its general morphology and the disposition of enamel. It is small and probably represents a small species, although it could be the tooth of a juvenile. Rotation of the apex of the crown and its gentle apicobasal taper, rather than conical shape, indicate that it is not the tooth of an ornithocheirid and it is clearly not a tooth of an istiodactylid. Among other toothed forms from the Late Jurassic and Early Cretaceous some members of the Ctenochasmatidae Nopcsa, 1928, particularly members of Gnathosaurinae Unwin, 1992, had teeth with morphology, including flexed apices, similar to that of IWCMS.2002.28. The specimen is therefore assigned with some confidence to the Ctenochasmatidae and tentatively to Gnathosaurinae.

Elsewhere, gnathosaurine pterosaurs have been recorded from the Far East, Europe and South America over a period spanning the Late Jurassic and Early Cretaceous: Huanhepterus quingyangensis Dong, 1982, is from the Upper Jurassic (exact age uncertain) Huachihuanhe Formation of Gansu, China; Gnathosaurus subulatus and "Pterodactylus" longicollum are from the Tithonian Solnhofen Limestone Formation of Germany (Wellnhofer 1970, 1991; Buisonjé, 1981): Plataleorhynchus streptophorodon Howse and Milner, 1995, is from the Berriasian Purbeck Limestone Formation of southern England; Beipiaopterus chenianus Lü, 2003, referred with some uncertainty due to the lack cranial material, is from the Barremian Yixian Formation of Liaoning Province, China as is Gegepterus changi Wang et al., 2007; Cearadactylus atrox Leonardi and Borgomanero, 1985, is from the ?lower Albian Santana Formation of Chapada do Araripe, Brazil, (recently Vila Nova and Sayão (2009) have suggested that the Cearadactylus atrox holotype has been incorrectly repaired and that the distal rostrum has been reattached inverted. In their reappraisal in the light of this and their new phylogenetic analysis they consider C. atrox to form a clade with Ornithocheirus compressirostris); and un-named, possibly gnathosaurine remains have been reported from the ?Early Cretaceous (exact age uncertain) of Chile (Martill et al., 2006). The occurrence of a gnathosaurine ctenochasmatid in the Barremian Wessex Formation is, therefore, consistent with the temporal and geographical distribution of Gnathosaurinae.

Azhdarchoidea Nessov, 1984, sensu Unwin, 1992

Neoazhdarchia Unwin, 2003

Indeterminate Neoazhdarchia
Witton et al. (2009) described a single, but well preserved pterosaur humerus from the Wessex Formation of the Isle of Wight which they referred to the Neoazhdarchia on account of the overall shape and the nature of the deltopectoral crest. Furthermore, they considered that it was non-azhdarchid as the deltopectoral crest was not sufficiently isolated from the proximal humerus. They were also able to rule out a lonchodectid affinity where the deltopectoral crest is located far more proximally. Thus the specimen was regarded as a non-lonchodectid, non-azhdarchid azhdarchoid. Thus this specimen (casts are accessioned in the Staatliche Museum für Naturkunde Karlsruhe [PAL 9876], BMNH [R 16497] and IWCMS [2008.201]) indicates a pterosaur with affinities to Thalassodromidae or Chaoyangopteridae, the precise relationships of which remain to be determined.

Ornithocheiroidea Seeley, 1891

Istiodactylidae Howse, Milner and Martill, 2001

Istiodactylus Howse, Milner and Martill, 2001

Istiodactylus latidens (Seeley, 1901)

\section{Istiodactylus $\mathrm{sp}$.}

Four teeth, IWCMS.2002.25-26, 2009.474-475 (Fig. $6 \mathrm{~A}-\mathrm{K})$ recovered from residues during bulk screening for microvertebrate remains are comparable with the teeth of Istiodactylus latidens as seen in BMNH R3877 and CAMMZ T706, both of which were examined during this study. These specimens are, therefore, referred to Istiodactylus and with less confidence to I. latidens (Seeley, 1901). Another, IWCMS.2002.27 (Figs. 6J-K), can be referred to Istiodactylidae Howse et al. 2001 on the basis of its lateral profile and labiolingual compression and might belong to Istiodactylus sp. Two further specimens, IWCMS.2009.476-477 (Fig. 7) may also be referable to Istiodactylidae but not to Istiodactylus. Several recently discovered Chinese taxa have been referred to Istiodactylidae, including Istiodactylus sinensis Andres and Ji, 2006; Longchengpterus zhaoi Wang, Li, Duan and Cheng, 2006; Liaoxipterus brachyognathus Dong and Lü, 2005, Nurhachius ignaciobritoi Wang, Kellner, Zhou, and Campos, 2005 and Hongshanopterus lacustris Wang, Campos, Zhou and Kellner, 2008. Recently there has been some debate concerning synonymy among these taxa (Lü et al., 2006; Lü et al., 2008) and Haopterus gracilis Wang and Lü, 2001 has now been transferred from Pterodactylidae to Istiodactylidae (Lü et al., 2008) In some of these istiodactylids the teeth differ from Istiodactylus in being slightly more elongate (e.g Longchepterus), but in others they differ very little from Istiodactylus, making it very difficult to refer the teeth to 


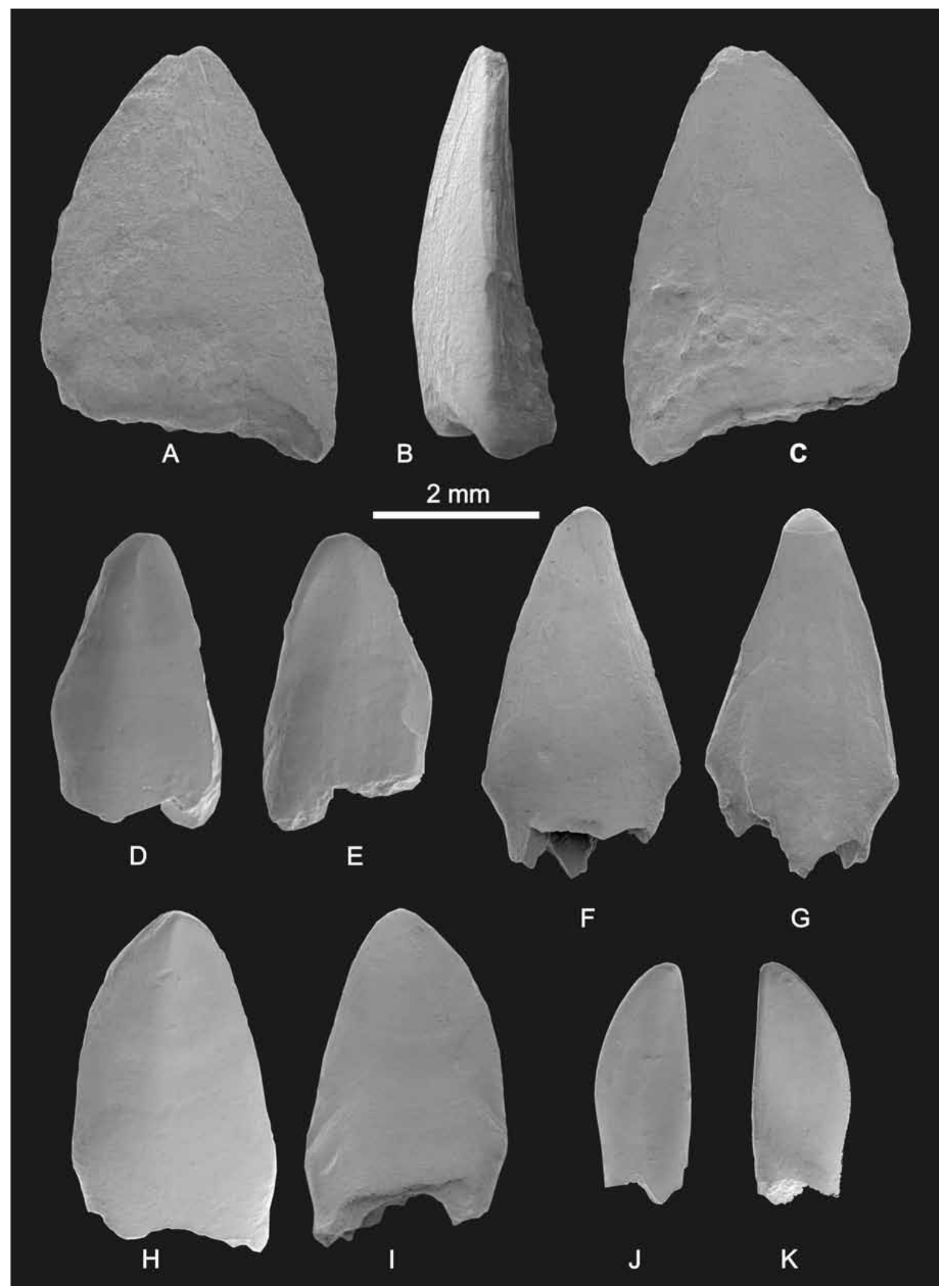

Fig. 6.- Istiodactylus teeth from the Wessex Formation. A-C, IWCMS.2009.474: A, labial view; B, mesial view; C, lingual view. D-E, IWCMS.2002.26: D, labial view; E, lingual view. F-G, IWCMS2009.475: F, labial view; G, lingual view. H-I, IWCMS.2002.25: H, labial view; I, lingual view. J-K, IWCMS.2002.27: J, labial view; K, lingual view.

Fig. 6.- Diente de Istiodactylus de la Formación Wessex. A-C, IWCMS.2009.474: A, vista labial; B, vista mesial; C, vista lingual. D-E, IWCMS.2002.26. D: vista labial; E, vista lingual. F-G, IWCMS2009.475: F, vista labial; G, vista lingual. H-I, IWCMS.2002.25: H, vista labial; I, vista lingual. J-K, IWCMS.2002.27: J, vista labial; K, vista lingual. 
a genus with confidence. IWCMS.2009.476-477 are thus considered here to be Istiodactylidae indet.

IWCMS.2009.474-475 and 2002.25-26 (Fig. 6A-I) have many characters in common and all fall within the range of morphological variation observed in teeth in the rostra (BMNH R3877, see Howse et al., 2001, Pl. 45, Figs. 3-4 and P1. 46, 1-2, and CAMMZ T706, pers. obs.) referred to Istiodactylus latidens. IWCMS.2009.474 and 2002.25 are similar in gross morphology but differ in mesiodistal width. In IWCMS.2009.474 (Fig. 6A-C) crown height measured lingually along the centre line is $4.4 \mathrm{~mm}$, although the apex of the tooth is somewhat abraded. Mesiodistal crown width in this specimen is $3.6 \mathrm{~mm}$. In IWCMS.2002.25 (Fig. 6H-I) crown height is also $4.4 \mathrm{~mm}$ but this tooth is somewhat narrower than IWCMS.2009.474 with a maximum crown width of 3.1 $\mathrm{mm}$. Both are laterally compressed, blade-like with sharp mesial and distal carinae and in lingual/labial view are triangular in outline with convex mesial and distal margins, and a basal constriction above the root. Both have gently convex labial surfaces bearing a low ridge extending from $c$. one third of the distance from the base of the crown to the apex. In IWCMS.2009.474 this ridge occupies an approximately central position and in IWCMS.2002.25 it lies somewhat distal to the centre-line of the crown. In IWCMS.2002.25 enamel covers a little less than one half of the crown apically on the lingual side and $c$. two thirds of the apical part of the crown labially. It appears to be similar in IWCMS.2009.474 but is not well preserved in this specimen which is also variably covered in a siderite veneer. The lingual surfaces are convex and slightly apicobasally concave. The bases of both crowns below the enamel are somewhat labiolingually expanded. The mesial carinae are worn. In IWCMS.2002.25 wear extends to about half the distance from the apex to the base of the enamel. In IWCMS.2009.474 wear extends to the base of the mesial carina but is more pronounced apically. Distally, wear appears to be minimal. In this specimen there is a wear facet descending from the apex of the crown on the mesiolingual surface. This extends to about half the distance to the base of the crown. This is not readily discernable in the scanning electron micrograph (Fig.6C) because the specimen was uncoated and in order to avoid charging the image was taken at an acceleration voltage of $1 \mathrm{KV}$. The distal carina of IWCMS.2002.25 is unworn but it bears a number of scratches lingually. These lie almost perpendicular to the distal carina but are somewhat apically inclined. Faint scratches can be seen on the labial side of IWCMS.2002.25 but it is not clear whether they represent abrasion during feeding or postmortem. Due to its state of preservation, scratches are not visible on IWCMS.2009.474

IWCMS2002.26 and 2009.475 (Fig. 6D-G) resemble IWCMS. 2002.25 and 2009.474 in many respects. Both are laterally compressed, blade-like with sharp mesial and distal carinae and in lingual/labial view are triangular in outline. However, unlike the previously described specimens these have less mesially convex mesial margins and essentially straight distal margins. Both have a basal constriction above the root, this being particularly pronounced in IWCMS.2009.475. In IWCMS.2002.26 (Fig. 6D-E) crown height and width are estimated due to slight damage. The former is $c .3 .5 \mathrm{~mm}$ and the latter $c$. $2.1 \mathrm{~mm}$. In IWCMS.2009.475 (Fig. 6F-G) crown height is also estimated to be $c .3 .7 \mathrm{~mm}$, uncertainty being due to the presence of wear at the apex and preservation of a small part of the root which renders determination of the base of the crown somewhat problematic, Crown width in this specimen is $2.4 \mathrm{~mm}$. As in the previously described specimens, a ridge is present on the apicobasally and mesiodistally convex labial surfaces of both IWCMS.2002.26 and 2009.475. In both specimens this lies somewhat mesial to the centre-line of the crown. Also as in the previously described specimens, the lingual surfaces are lingually convex and slightly apicobasally concave. In IWCMS.2002.26 enamel covers a little less than one half of the crown apically on the lingual side and $c$. two thirds of the crown labially. IWCMS.2009.475 has a somewhat rugose texture, particularly lingually where it covers about half of the apical part of the crown. Labially it covers slightly more than half of the apical part of the crown. The bases of both crowns below the enamel are somewhat labiolingually expanded. In IWCMS.2002.26 the distal carina is unworn and apical wear of the mesial carina resembles that described for IWCMS.2002.25. However, in this specimen it is more pronounced. It extends to the base of the preserved enamel, the basal extremity being broken away. This specimen also differs from IWCMS.2002.25 in having a swelling mesiolingually at the apex of the crown the lingual surface of which is worn. The distolingual surface is also worn in this specimen and towards the base of the distal surface there is a well-developed, triangular wear facet. This has probably formed as a result of occlusion with the opposing dentition. The lingual surface of IWCMS.2002.25 bears a number of scratches. These lie almost perpendicular to the distal surface but are somewhat apically inclined. A more steeply inclined scratch extends from close to the base of the crown distally to the mesial margin of the crown lingually. Faint scratches can be seen on the labial surface of IWCMS.2002.26 but it is not clear whether they represent abrasion during feeding or post-mortem. 
Only one scratch can be seen on the on the lingual surface of IWCMS.2009.475 suggesting that it may have been acquired post-mortem. Wear affecting the carinae of IWCMS.2009.475 differs from that seen in other specimens. It is limited to the basal part of both and extends apically for about half the distance to the apex of the crown distally and somewhat further mesially. These facets appear to have formed in response to occlusion with the opposing dentition. The basal-most parts of both carinae on this specimen also differ from other specimens in comprising small labial and lingual convex swellings. Wear at the apex of this tooth also differs from other specimens in comprising an oblique lingually inclined, apically convex facet which has breached the enamel. This appears to represent dietary attrition rather than occlusion.

WCMS.2002.27 (Fig. 6J-K) is both smaller and more mesiodistally compressed than any of the previously described specimens. Crown height is $2.8 \mathrm{~mm}$ and maximum crown width is $1.3 \mathrm{~mm}$. It is labiolingually compressed and blade-like. Enamel extends to about three quarters of the distance from the apex to the base of the crown lingually and although very thin basally, it appears to cover the entire labial surface. The crown is unworn but the apex has been slightly blunted, perhaps post-mortem. Unlike previously described specimens, the lingual surface is labially concave and bears a low central ridge apically. The lingual surface is also apicobasally concave but is slightly flexed labially and distally at the apex. Labially the crown is convex basally but less so apically. Both the distal and mesial carinae are unworn, the mesial margin being convex mesially and the distal margin almost straight.

\section{Discussion}

Although differing from IWCMS.2002.25-26, and 2009.474-475 in a number of details, IWCMS.2002.27 is similar to these specimens in its blade-like morphology and in the presence of a ridge on the labial surface. Enamel disposition is consistent with it being the tooth of a pterosaur. That being the case it can also be assigned to Istiodactylidae but whether or not it is a tooth of $I s-$ tiodactylus is open to question. If it is, its small size and differences in morphology to the teeth of Istiodactylus latidens as seen in BMNH R3877 and CAMMZ T706 may indicate that it is the tooth of a juvenile.

\section{Localities, horizons and temporal distribution}

The stratigraphic distribution of specimens is shown in Figure 2. IWCMS.2002.25 and 2009.474-475 were collected from bed 38 occurring close to the top of the
Wessex Formation at Yaverland National Grid Reference SZ 61693 85223. IWCMS.2002.26 was collected from bed L9 on the southwest-coast of the island, north-west of Grange Chine at National Grid Reference SZ 4389180530 . This bed occurs $c .115 \mathrm{~m}$ lower in the succession than bed 38 (Stewart, 1978; Radley, 1994). IWCMS.2002.27 was collected from bed CL3 in Compton Bay at National Grid reference SZ 37847 83910. This lies c. $48 \mathrm{~m}$ above the base of the exposed Wessex Formation, placing it somewhat lower in the succession than L9 (correlation uncertain, Stewart, 1978). These records, together with those from the Vectis Formation indicate that Istiodactylus was present throughout most if not all of the Barremian and into the early Aptian. They also serve to confirm that the holotype material of I. latidens (BMNH R176) could have been derived from the Wessex Formation exposed in Brook Bay and not from the Vectis Formation exposed to the north-west in Compton Bay, which occurs about $1.5 \mathrm{~km}$ from the village of Brook. (Fig. 1).

\section{Istiodactylidae indet.}

IWCMS.2009.476 (Fig. 7A-C) was collected from bed 38 at Yaverland, National Grid Reference SZ 61693 85223 (Figs.1-2). It is identified as the tooth of a pterosaur on the basis of enamel disposition as further described below. It is triangular in lateral profile and blade-like and in these respects it resembles teeth described above referred to Istiodactylus. However, it differs from these in: its sharply pointed apex; fluted lateral margins of equal length (which do not permit determination of which is the mesial and which the distal carina); lack of a ridge on the labial surface; lack of labiolingual inflation at the base of the crown; lack of basal constriction; lack of labial concavity on the lingual side; possession of a pronounced wear facet incorporating a narrow groove on one of the carinae (Fig. 7A (arrowed), B) which intersects the apicobasal axis of the crown at a very acute angle basally. Crown height is $2.9 \mathrm{~mm}$ and the width is $2.3 \mathrm{~mm}$. The labial surface is gently convex both apicobasally and mesiodistally. A shallow depression is present basally either slightly mesial or distal to the centre-line of the crown (on the right hand side in Fig. 7A). This extends from the base to a little more than half the distance to the apex. The lingual surface is similarly convex apically but there is a shallow concavity basally. The apicobasal radius of curvature of the labial side is greater that that of the lingual side placing the apex of the crown somewhat lingual to the mesiodistal centreline of the base. Wear extends along the whole of one carina but is less pronounced apically on the carina bearing the wearare facet described above. Wear has removed the generally reflective enamel 


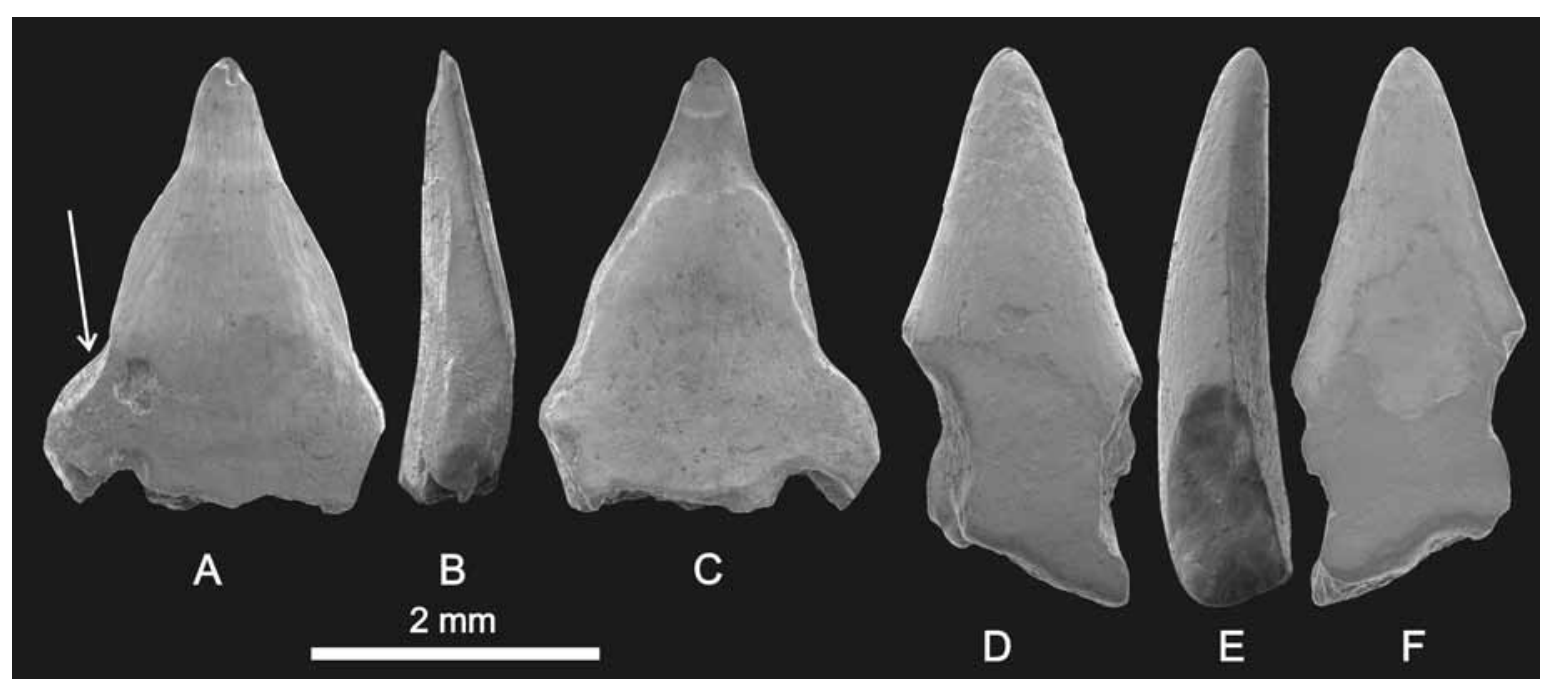

Fig. 7.- Istiodactylid teeth from the Wessex Formation. A-C, IWCMS.2009.476: A, labial view; B, mesial or distal view; C, lingual view. D-F, IWCMS.2009.477: D, labial view; E, mesial or distal view; D, lingual view.

Fig. 7.- Diente de Istiodactylidae de la Formación Wessex. A-C, IWCMS.2009.476: A, vista labial; B, vista mesial o distal; C, vista lingual. D-F, IWCMS.2009.477: D, vista labial; E, vista mesial o distal; F vista lingual.

apically on the lingual side but not labially. Lingually the apex of the tooth has been chipped. It is not clear whether this occurred pre- or post-mortem. Labially enamel covers about three quarters of the apical part of the tooth. Before wear it would have covered approximately half of the apical part lingually. Basally the tooth is mesially and distally expanded but one side is partially broken away.

IWCMS.2009.477 (Fig. 7D-F) was collected from bed L9 on the southwest-coast of the island, north-west of Grange Chine at National Grid Reference SZ 4389180530 (Figs. 1-2). Parts of the lower part of the crown are lost to breakage mesially, distally and basally and slight polishing of the broken surfaces suggests that breakage occurred before final burial. As preserved the tooth has a height of $c .3 .6 \mathrm{~mm}$ and a width of $c .1 .7 \mathrm{~mm}$. it is labiolingually compressed but much less so than IWCMS.2009.476, the degree of compression resembling that seen in teeth referred to Istiodactylus. It differs from all of these in having a symmetrical, straight-sided triangular lateral profile, the location of the carinae which are placed more lingually than in other specimens, and in the disposition of enamel. Except where damaged post-mortem, enamel, which is less reflective than that of IWCMS.2009.476 but similar to that of teeth referred to Istiodactylus, covers the lingual surface entirely but is restricted to the apical two thirds of the crown labially. The carinae also differ from IWCMS.2009.476 and from those of teeth referred to Istiodactylus in being much less knife-like and in being devoid of wear and/or facets. IWCMS.2009.477 resembles IWCMS.2009.476 but differs from teeth referred to Istiodactylus in lacking labiolingual expansion of the crown basally and in lacking a ridge on the labial surface. Damage prevents determination of the basal profile of the crown. IWCMS.2009.477 resembles teeth referred to Istiodactylus in having a lingual surface that is lingually convex but labially concave apicobasally. It also resembles these teeth in having a labially convex labial surface. However, IWCMS.2009.477 differs from these in having very symmetrical convexities both labially and lingually. The unworn apex of the tooth is less pointed that that of IWCMS.2009.476 but more pointed that the teeth referred to Istiodactylus.

Based on their triangular profile and labiolingual compression, IWCMS.2009.476 and 477 are referable to Istiodactylidae Howse, Milner and Martill, 2001 but neither can be referred to Istiodactylus. Differences in morphology suggest that they do not represent teeth from different positions in the jaw of a taxon with heterodonty and that they therefore represent separate taxa. The enamel disposition seen in IWCMS.2009.477 is unusual but this and the general morphology of the tooth suggests that this is the tooth of a pterosaur. That being the case, at least three istiodactylids are present in the Wessex Formation pterosaur assemblage.

Euornithocheiridae Unwin, 2003

Ornithocheiridae Seeley, 1870

Caulkicephalus Steel, Martill and Unwin, 2005

Caulkicephalus trimicrodon Steel, Martill and Unwin, 2005 Holotype: IWCMS 2002.189.1, 2, 4.

Referred material found at same locality and horizon: IWCMS 2002.189.3, 233, 234.1, 236, 237; 2003.2-4. 

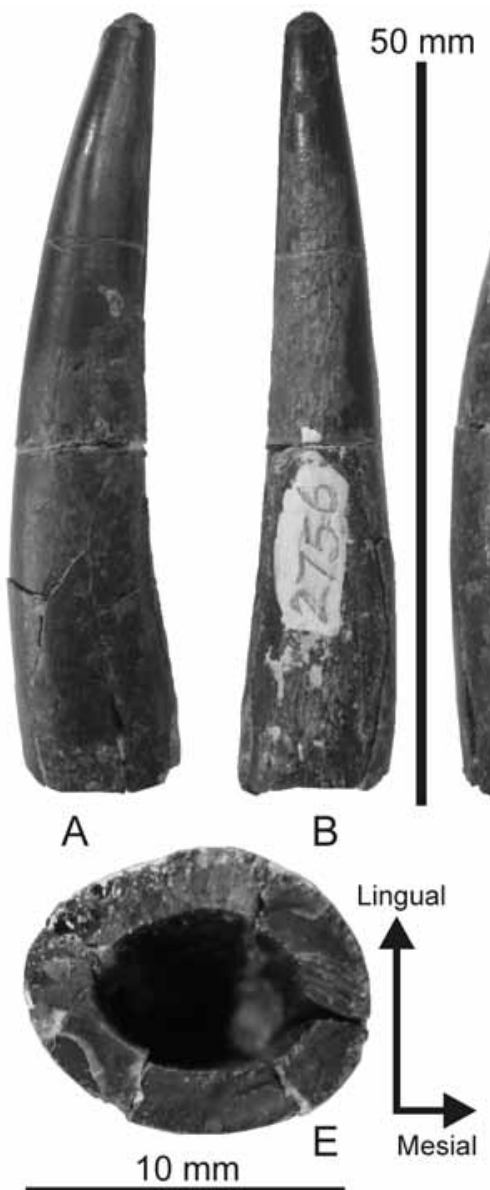

$10 \mathrm{~mm}$
A

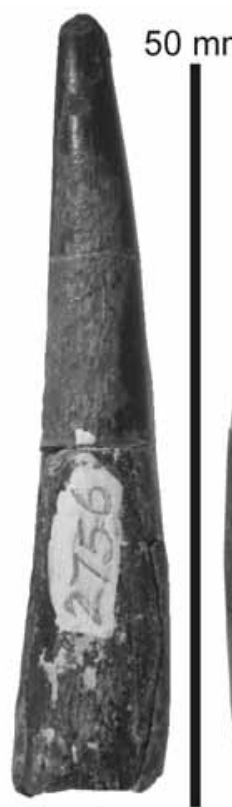

B
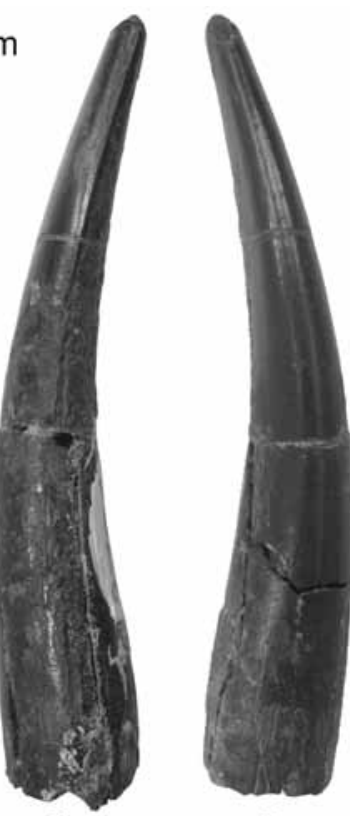

C

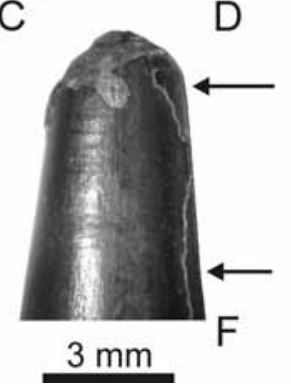

Fig. 8.- MIWG 2756 in: A, labial view; B, lingual view; C, distal view; $\mathrm{D}$, mesial view; E, basal view, arrows for orientation; $\mathrm{F}$, enlargement of tooth tip to show wear and small areas of adhering enamel (arrowed)

Fig. 8.- MIWG 2756 en: A, vista labial; B, vista lingual; C, vista distal; D, vista mesial; E, vista basal, las fechas indican orientación; F, aumento de la punta del diente del diente para mostrar el desgaste y pequeñas áreas de esmalte adherente (mostrados con una flecha).

Tentatively referred material not included in the original description: MIWG 2756 (Fig. 8) a substantially complete tooth crown found at the same locality and from the Wessex Formation but horizon unrecorded.

This taxon was first described by Steel et al. (2005) who erected a distinct genus for fragmentary cranial material of clear euornithocheiran affinity on the basis of its distinctive dentition, dental arrangement, and crest configuration. It is similar in some respects to material assigned to Ludodactylus, Anhanguera and possibly Brasileodactylus, but until a complete revision of these forms becomes available, the status and relationships of Caulkicephalus remain uncertain.

MIWG 2756 (Fig. 8), a substantially complete lower left or upper right tooth crown was collected from the
Wessex Formation at Yaverland in the 1920s, when it was identified as a hybodont shark fin spine. As such it remained largely ignored until 2002 when a re-examination of small vertebrate material in the collections of the Isle of Wight County Museum Service was undertaken by the first author. During this study it was re-identified as the tooth of an ornithocheirid pterosaur.

Crown height as preserved is $52 \mathrm{~mm}$ (Fig. 8A-D). The tooth is somewhat labiolingually compressed with an oval basal cross-section: mesiodistal length $11 \mathrm{~mm}$; labiolingual width $9 \mathrm{~mm}$. A deep pulp cavity, partly filled by matrix is present (Fig. 8E). The tooth wall surrounding this is robust being $2 \mathrm{~mm}$ thick. Dietary attrition has removed part of the apex (Fig. 8F). Here the enamel had been completely removed and the dentine pitted and eroded but raised areas of the latter have also been polished apparently pre-mortem. As preserved, the crown has an apical cross-sectional length and width of $3.25 \mathrm{~mm}$ and $2.22 \mathrm{~mm}$ respectively. The crown is somewhat distally recurved with a convex mesial surface and a concave distal surface (Fig. 8A). It is also lingually flexed with apicobasally convex labial and concave lingual surfaces (Fig. 8C-D). In cross-section the labial, lingual and mesial surfaces are smoothly convex. In contrast, the distal surface comprises a blunt carina. Enamel is mostly missing except apically on the lingual side and along the apical part of the distal carina to approximately one third of the distance to the base of the crown. Where present it is smooth and reflective except on the distal carina where it is somewhat rugose. Lingually a number of scratches on the enamel can be seen lying at an obtuse angle distally to the apicobasal axis of the crown. These appear to be attributable to abrasion during feeding rather than post-mortem because scratches are otherwise absent. The labial surface of the tooth is smooth but becomes less reflective for about half its length basally (Fig. 8A). Lingually the apex is smooth but the distal half of this surface from a distance approximately $10 \mathrm{~mm}$ below the apex is rugose and appears to comprise an area of etched enamel (Fig. 8B). While it is not possible to be certain due to its state of preservation, it appears that enamel may have been present to the base of the smooth area on the labial side and possibly to the base of the crown, at least distally on the lingual side. Many basally convex growth lines can be seen in the dentine labially. They are less distinct lingually. A slight constriction at the base of the tooth suggests that the crown is substantially complete.

Steel et al. (2005, Table 2, p. 693) provide maximum diameters for the first ten pairs of dental alveoli in Caulkicephalus trimicrodon. Pairs 5-7, with diameters of between 5.5 and $6 \mathrm{~mm}$, are the smallest in the anterior 
dentition and substantially smaller (as alluded to in the specific name) than alveoli anterior and posterior to them. Of these, tooth pairs 2 and 3 have the largest alveoli with maximum diameters of 14 and $15 \mathrm{~mm}$ respectively. The remainder are between 9-11 mm maximum diameter and in all alveoli this dimension is (with respect to the teeth) mesiodistally orientated. In MIWG 2756 the maximum basal diameter of the crown is also orientated mesiodistally and at $11 \mathrm{~mm}$ falls within the range recorded for Caulkicephalus. Based on these criteria and its provenance, there is nothing to preclude attribution of MIWG 2756 to this taxon.

\section{Pterosauria indet.}

IWCMS.2002.29 (Fig. 9) was obtained from bed L2 at Sudmoor Point (Fig. 2) on the south-west coast of the island at National Grid Reference SZ 3945182727 and from the sample that yielded IWCMS.2002.28 described above (Fig. 5). It comprises a partial tooth crown from which the apex and the basal part of the presumed distal edge are missing. As preserved, the crown height is 4.7 $\mathrm{mm}$ and width is $2 \mathrm{~mm}$. It is strongly labiolingually compressed (Fig. 9A). Labially, enamel extends from what remains of the apex to $c$. two thirds of the distance to the base of the crown. Lingually it is restricted to $c$. one third of the distance form the apex to the base. At the apex, the broken surface shows the enamel to be very thin. On the basis of these characters the tooth is identified as pterosaurian. Labially, the enamel bears a large number of basally concave ridges of low relief which lie perpendicular to the apicobasal axis of the crown, probably representing growth lines. Lingually the enamel is unornamented and on both surfaces the enamel is unaffected by wear. However, towards the base on the lingual side a number of faint parallel scratches can be seen which lie basally at about 45 degrees to the mesial margin of the crown. The mesial margin is convex mesially and the distal edge is concave mesially. The labial surface is slightly convex both apicobasally and mesiodistally. The lingual surface is convex labially, the convexity being stronger basally and mesially. This is reflected in the basal outline which before breakage would have been broader mesially than distally. Where preserved, the distal margin comprises a well defined crest. The mesial margin comprises a sharp crest which is folded lingually towards the base, where it becomes somewhat rugose. This does not extend entirely to the base of the crown terminating a short distance above it at the commencement of a slight basal constriction.

\section{Affinities}

No pterosaur with tooth morphology similar to that of IWCMS.2002.29 appears to have been described. The

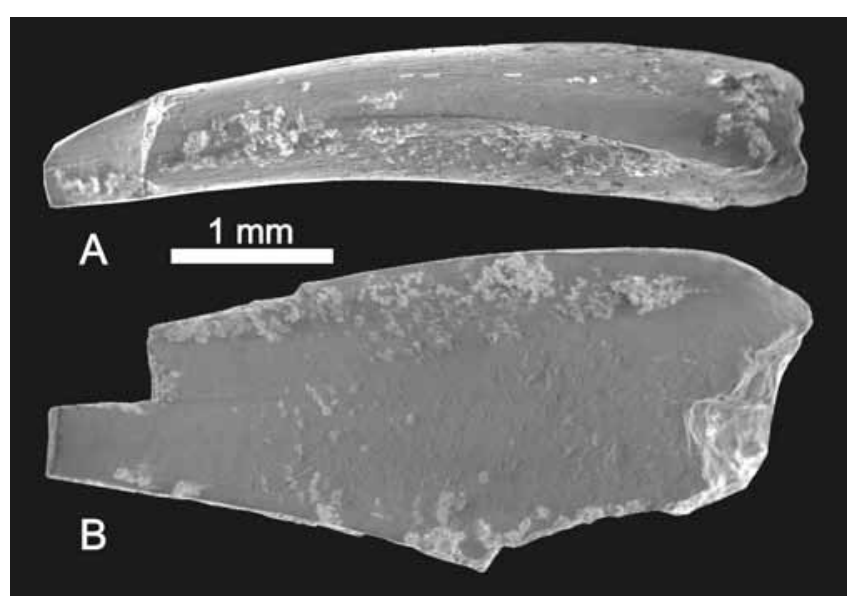

Fig. 9.- IWCMS.2002.29 in: A, mesial view; B, lingual view. Fig. 9.- IWCMS.2002.29 en : A, vista mesial; vista lingual.

lingually inclined ridge seen towards the base of the mesial margin of the tooth is reminiscent of the ridges seen in IWCMS.2002.28 from the same horizon, but similar structures have not been described for other taxa. Their taxonomic significance is therefore uncertain. If IWCMS.2002.29 does belong to the same species as IWCMS.2002.28 it would appear to have had a unique dentition adapted rostrally for dislodging relatively large prey items from soft substrates which were then processed by robust teeth in the posterior part of the dentition. The wear observed on the presumed apicodorsal surface of IWCMS.2002.28 is consistent with this feeding model. However until further and better material is available association of IWCMS2002.28 with IWCMS.2002.29 remains entirely speculative and appears unlikely based on the dentitions of other taxa. Strong labiolingual compression of the crown and its triangular lingual/labial profile suggest that IWCMS.2002.29 may be referable to Istiodactylidae (see Wang et al., 2008 for a discussion) but with currently available data this can not be confirmed. Nevertheless, IWCMS.2002.29 does suggest the presence of another hitherto unknown pterosaur in the Wessex Formation assemblage.

\section{Ornithocheirus nobilis Owen, 1870 (nomen dubium)}

The holotype of Ornithocheirus nobilis Owen, 1870 (BMNH 36552) (Fig. 4) is a straight, mid-shaft portion of long bone $102 \mathrm{~mm}$ in length, with an oval cross section with diameters of $30 \mathrm{~mm}$ and $23 \mathrm{~mm}$. It is thin-walled and the sectioned face shows no internal trabeculae. It has no diagnostic features to suggest its taxonomic affinity other than the thin wall which is indicative of Pterosauria. Furthermore, the lack of features makes it impossible to accurately identify which element of the skeleton it represents. Owen (1870) only figured BMNH 36552, but 
Lydekker (1888) states that other bone fragments were associated with it which he lists as BMNH 36552a.

Despite its indeterminate nature, the preservation of BMNH 36552 is rather good. The bone is black, is 3-D and lacks any cracking. The interior is filled with sediment, but crystalline pyrite, often associated with bone from the Wessex Formation, and somewhat unstable, is not present. Originally part of the Mantell collection, though not specifically mentioned in his catalogue of 1834 , one wonders why Owen erected a new taxon for such an inadequate specimen, and consequently, Howse et al. (2001) recommend $O$. nobilis should be regarded as nomen dubium.

\section{Indeterminate? pterosaur ungual}

A sample taken from bed 38 at Yaverland, National Grid Reference SZ 61693 85223, yielded IWCMS.2002.30, a possible pterosaur ungual phalanx (Fig. 10). It was recovered in four parts from three residue fractions. Unlike other ungual phalanges recovered from the Wessex Formation and a number of ungual phalanges of extant birds examined by one of us, which are composed of solid bone (SCS pers. obs.), IWCMS.2002.30 is hollow and of light construction. However it bears deep lateral grooves for the attachment of what was probably a substantial keratinous claw and possessed (prior to post-mortem damage) a robust flexor tubercle. These features suggest that IWCMS.2002.30 may be the ungual phalanx of a pterosaur.

\section{Discussion and conclusions}

Pterosaurs are very rare in the Wessex Formation and indeed in the Wealden Supergroup of Britain as a whole. Furthermore, most of what has been recorded is extremely fragmentary. From the Wealden of mainland Britain (Valanginian to Barremian/earliest Aptian) two taxa are currently considered valid: Coloborhynchus clavirostris Owen, 1874 and ?Lonchodectes sagittirostris (Owen, 1874), both of which come from the Hastings Group and therefore are considerably older than the Wessex Formation pterosaur assemblage. However, the recent pterosaur discoveries reported by Steel et al. (2005) and Witton et al. (2008), the systematic microvertebrate sampling of Sweetman (2006b, 2007, 2009b and reported here) along with a re-evaluation of pterosaur material housed in UK collections indicates a much higher diversity pterosaur assemblage for the Wessex Formation than had previously been thought. The assemblage is now known to comprise at least one genus of Euornithocheiridae (Caulkicephalus), three Istiodactylidae (Istiodactylus, Istiodactylidae indet), a single undetermined ctenochasmatine, a non-

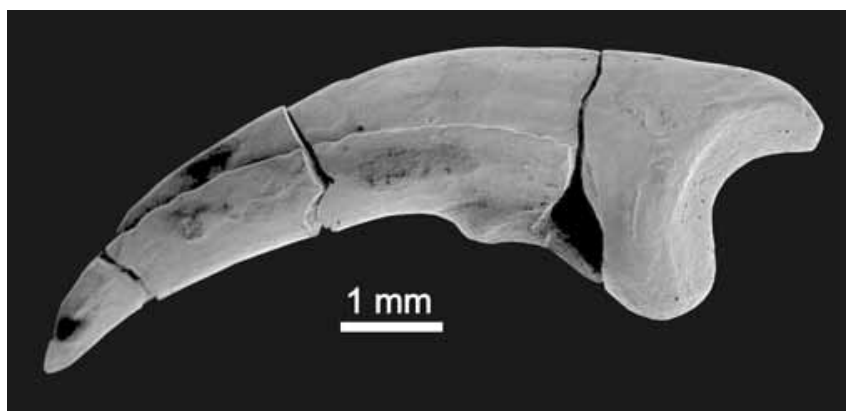

Fig. 10.- IWCMS.2002.30 ?pterosaur ungual phalanx from bed 38 of the Wessex Formation at Yaverland.

Fig. 10.- IWCMS.2002.30 falange ungueal del ? pterosaurio procedente de la capa 38 de la Formación Wessex en Yaverland.

lonchodectid, non-azhdarchid, azhdarchoid and an as yet undetermined taxon that in dental morphology is currently distinct from any of the aforementioned taxa but which may represent a fourth istiodactylid. This diversity is comparable to that observed elsewhere during the Early Cretaceous and in particular that recorded from the Barremian and early Aptian of China. The apparent absence of toothless forms in the Wessex Formation is worthy of comment. Few edentulous pterosaurs are known from the Barremian, although azhdarchoid taxa such as Tupuxuara, Tapejara and Tupundactylus from the Aptian-Albian of Brazil and Sinopterus from the late Barremian or early Aptian of China do attest to high Early Cretaceous diversity among toothless forms. The apparent absence of toothless forms in the Wessex Formation may therefore be an artefact of preservation and/or collecting bias.

A number of reptile genera are common to the Barremian terrestrial vertebrate assemblages of Britain and Spain. Large taxa include crocodiles and dinosaurs (Sánchez-Hernández et al., 2007) and some conspecific taxa have been recorded, e.g. Iguanodon bernissartensis and I. atherfieldensis (Weishampel et al., 2004). However, in a recent review of the taxonomy of iguanodont dinosaur genera and species Paul (2008) concluded that material from Spain probably cannot be reliably diagnosed to species or even genus and should be conservatively reassessed. This may apply to other large taxa because among small taxa including the scincomorph lizard Meyasaurus and the plagiaulacoid multituberculate mammal Eobaatar, genera common to the Early Cretaceous of both Britain and Spain (Sweetman, 2007, 2009a), no conspecific taxa have yet been recorded. This may also be the case for volant forms despite their potential ability to transcend the apparently modest marine barriers separating Britain from Iberia during the Late Jurassic and Early Cretaceous (e.g. Scotese, 2002). The Early Cretaceous of Spain has yielded a diverse avian assemblage (e.g. Chiappe and Witmer, 2002 and references there in). In contrast, birds 
are only questionably known from the Early Cretaceous of mainland Britain (Harrison and Walker, 1973; Olson, 1995) and as yet only very rare isolated teeth of birds have been recovered from the Wessex Formation (SCS pers. obs.). While at least one of these may represent an enantiornithine (Luis Chiappe pers. comm. to SCS 2009) currently available material does not permit comparison with the avian assemblages of Spain. In contrast, material representing the pterosaur assemblages does permit limited comparisons.

Ruiz-Omenãca et al. (1998, Figs. 1, 2a-i) reported pterodactyloid teeth from Barremian strata at Vallipón, Teruel, which may represent an istiodactylid. However, if this is the case they are morphologically distinct from istiodactylid teeth from the Wessex Formation. SánchezHernández et al. (2007) recorded more than 30 pterosaur teeth from the Barremian Camarillas Formation at Galve representing ornithocheirids, istiodactylids, dsungaripterids and possible gnathosaurine ctenochasmatoids. This assemblage has similarities to that of the Wessex Formation, but the descriptions and figured specimens do not permit detailed comparisons. However, the istiodactylid tooth (Sánchez-Hernández et al., 2007, "morphotype 4" Fig. 5D) also appears to be morphologically distinct from istiodactylid teeth from the Wessex Formation. Recently, Vullo et al. (2009a) described four isolated teeth from the Barremian La Huérguina Formation at Las Hoyas, Cuenca. Two of these represent an indeterminate istiodactylid with tooth morphology apparently similar to the anteriormost teeth of Haopterus, an istiodactylid from the Chinese, Barremian, Yixian Formation (Wang and Lü, 2001). These teeth are also not comparable to istiodactylid teeth from the Wessex Formation and represent a distinct taxon. The two further teeth from Las Hoyas represent an indeterminate ornithocheirid. While an ornithocheirid, Caulkicephalus trimicrodon Steel et al., 2005, has been recorded from the Wessex Formation, the type material representing this taxon lacks teeth and comparisons with the Las Hoyas specimens can not be made. However, MIWG 2756 (Fig. 8) from the Wessex Formation, tentatively referred here to Caulkicephalus, is similar in gross morphology to one of two ornithocheirid teeth figured by Vullo et al., 2009a, (Fig. 3c) although the latter is significantly smaller (height $37 \mathrm{~mm}$ compared to $52 \mathrm{~mm}$ for the Wessex Formation specimen). The other, (Fig. 3d), while similar in apical crown morphology, would if complete, also have been smaller than MIWG 2756. Although the Las Hoyas specimens are similar in gross morphology to MIWG2756 and ornithocheirids generally have heterodont dentitions in terms of tooth size (rather than gross morphology), individual, isolated teeth can only be diagnosed to family level. In view of this, referral of the
Spanish specimens to Caulkicephalus would be unsound, even if the type material of that taxon included teeth. Recently Vullo et al. (2009b) reported the presence of Tapejaridae in the Las Hoyas deposits, a group that has not yet been recorded from the Wessex Formation. From material currently available it appears that the Barremian pterosaur assemblages of Britain and Spain, while showing general similarities, probably differ from each other at species level. This observation is compatible with observations made in connection with other groups, e.g. lizards and mammals, and is indicative of a substantial period of geographical isolation and endemism during the Late Jurassic and Early Cretaceous.

\section{Acknowledgements.}

Thanks to Robert Loveridge and Carmen Solana (University of Portsmouth) for light photography and help with Spanish translations respectively, and to Steve Hutt (Dinosaur Isle, Isle of Wight), Sandra Chapman and Angela Milner (NHM, London), and Jenny Clack (CAMZ, Cambridge) for access to specimens in their care. Also to Jon and Lou Moody for donation of Vectis Formation specimens IWCMS.2009.471-2 figured here. We have benefited from discussions with Mick Green, Steve Hutt, Martin Munt, Darren Naish, Lorna Steel, Helmut Tischlinger, David Unwin and Mark Witton. We thank Alexander Kellner and Romain Vullo for their helpful reviews of an early draft of this manuscript, and Ángela Delgado for her comments and editorial assistance.

\section{References}

Allen, P. (1998): Purbeck-Wealden (early Cretaceous) climates. Proceedings of the Geologists' Association, 109: 197-236. http://dx.doi.org/10.1016/S0016-7878(98)80066-7

Andres, B., Ji, Q. (2006): A new pterosaur from the Liaoning Province of China, the phylogeny of the Pterodactyloidea, and the convergence in their cervical vertebrae. Palaeontology, 51: 453469. http://dx.doi.org/10.1111/j.1475-4983.2008.00761.x

Benton, M. J., Spencer, P. S. (1995): Fossil Reptiles of Great Britain. Chapman \& Hall, London: 386 p.

Buisonjé, P. H. de. (1981): Ctenochasma porocristata nov. sp. from the Sonhofen Limestone, with some remarks on other Ctenochasmatidae. Proceedings of the Koninklijke Nederandse Akademie van Wetenschappen, Series B, 84: 411-436.

Chiappe, L. M., Witmer, L. M. (eds.). (2002): Mesozoic birds: above the heads of dinosaurs. University of California Press, Berkley: $520 \mathrm{p}$.

Dong, Z. (1982): A new pterosaur (Huanhepterus quingyangensis gen. et sp. nov.) from Ordos, China. Vertebrata Palasiatica, 20: 115-121.

Dong, Z. and Lü, J. (2005): A new ctenochasmatid pterosaur from the Early Cretaceous of Liaoning Province. Acta Geologica Sinica, 79: 164-167. 
Evans, S. E., Barrett, P. M., Ward, D. J. (2004): The first record of lizards and amphibians from the Wessex Formation (Lower Cretaceous: Barremian) of the Isle of Wight, England. Proceedings of the Geologists' Association, 115: 239-247. http://dx.doi. org/10.1016/S0016-7878(04)80005-1

Falcon, N. L., Kent, P.E. (1960): Geological results of petroleum exploration in Britain 1945-1957. Memoir of the Geological Society of London, 2: $56 \mathrm{p}$.

Green, M. (1995): New pterosaur remains from the Isle of Wight. The Geological Society of the Isle of Wight, Newsletter, 1 (2): $18-23$.

Hankin, E. H., Watson, D. M. S. (1914): On the flight of pterodactyls. Aeronautical Journal, 18: 324-335.

Harrison, C. J. O., Walker, C .A. (1973): Wyleyia: a new bird humerus from the Lower Cretaceous of England. Palaeontology, 16: 721-728.

Hooley, R. W. (1913): On the skeleton of Ornithodesmus latidens: an ornithosaur from the Wealden Shales of Atherfield (Isle of Wight). Quarterly Journal of the Geological Society of London, 69: 372421. http://dx.doi.org/10.1144/GSL.JGS.1913.069.01-04.23

Howse, S. B., Milner, A. R. (1995): The pterodactyloids from the Purbeck Limestone Formation of Dorset. Bulletin of the British Museum of Natural History, London (Geology), 51: 73-88.

Howse, S. C. B., Milner, A. R., Martill, D. M. (2001): Pterosaurs. In: Martill, D. M., Naish, D. (eds.), Dinosaurs of the Isle of Wight. Palaeontological Association Field Guide to Fossils, 10, London: 324-355.

Hughes, N. F., McDougall, A. B. (1990): New Wealden correlation for the Wessex Basin. Proceedings of the Geologists' Association, 100: 85-90. http://dx.doi.org/10.1016/S00167878(08)80208-8

Insole, A. N., Hutt, S. (1994): The palaeoecology of the dinosaurs of the Wessex Formation (Wealden Group, Early Cretaceous), Isle of Wight, southern England. Zoological Journal of the Linnaean Society, 112: 197-215. http://dx.doi. org/10.1111/j.1096-3642.1994.tb00318.x

Kaup, J. J. (1834): Versuch einer Eintheilung der Saugethiere in 6 Stämme und der Amphibien in 6 Ordnungen. Isis, 3: 311-315.

Kellner, A. W. A., Tomida, Y. (2000): Description of a new species of Anhangueridae (Pterodactyloidea) with comments on the pterosaur fauna from the Santana Formation (Aptia-Albian), north eastern Brazil. National Science Museum Monographs, 17: $1-135$.

Kerth, M., Hailwood, E. A. (1988): Magnetostratigraphy of the Lower Cretaceous Vectis Formation (Wealden Group) on the Isle of Wight, southern England. Journal of the Geological Society of London, 145: 351-360. http://dx.doi.org/10.1144/ gsjgs.145.2.0351

Leonardi, G., Borgomanero, G. (1985): Cearadactylus atrox nov. gen., nov. sp.: novo Pterosauria (Pterodactyloidia) da Chapada do Araripe, Ceará, Brasil. DNPM, Coletânea de Trabalhos Paleontológicos. Série Geologia, 27: 75-80.

Lü J.C. (2003): A new pterosaur: Beipiaopterus chenianus, gen. et sp. nov. (Reptilia: Pterosauria) from Western Liaoning Province, China. Memoir of the Fukui Prefectural Dinosaur Museum, 2: 153-160.

Lü, J.C., Ji, S., Yuan, C., Ji, Q. (2006): Pterosaurs from China. Geological Publishing House, Beijing: 147 p. [in Chinese, with English figure captions]
Lü, J., Xu, L. and Ji, Q. (2008): Restudy of Liaoxipterus (Istiodactylidae: Pterosauria), with comments on the Chinese istiodactylid pterosaurs. In: Hone, D.W.E., Buffetaut, E. (eds.), Flugsaurier: pterosaur papers in honour of Peter Wellnhofer. Zitteliana, B28: 229-241.

Lü, J.C., Unwin, D. M., Jin, X., Liu, Y., Ji, Q. (2009): Evidence for modular evolution in a long-tailed pterosaur with a pterodactyloid skull. Proceedings of the Royal Society, B 277: 383-389. http://dx.doi.org/10.1098/rspb.2009.1603

Lydekker, R. (1888): Catalogue of the fossil Amphibia and Reptilia in the British Museum (Natural History), Part 1. Trustees of the $\mathrm{BM}(\mathrm{NH})$, London: $309 \mathrm{p}$.

Mantell, G. A. (1834): A descriptive catalogue of the collection illustrative of geology, and fossil comparative anatomy in the museum of Gideon Mantell LLD, FRS. $3^{\text {rd }}$ Edition, Relfe and Fletcher, London: 28 p.

Mantell, G. A. (1854): Geological excursions round the Isle of Wight and along the adjacent coast of Dorsetshire. $3^{\text {rd }}$ Edition, Peter and Galpin, London: 356 p.

Martill, D. M., Frey, E., Green, M., Green, M. E. (1996): Giant pterosaurs from the Lower Cretaceous of the Isle of Wight, UK. Neues Jahrbuch für Geologie und Paläontologie, Monatsefte, 1996: 672-683.

Martill, D. M., Frey, E., Bell, C. M., Diaz, G. C. (2006): Ctenochasmatid pterosaurs from Early Cretaceous deposits in Chile. Cretaceous Research, 27: 603-610. http://dx.doi.org/10.1016/j. cretres.2006.03.002

Martill, D. M., Naish, D. (eds.). (2001): Dinosaurs of the Isle of Wight. Palaeontological Association, London, Field Guides to Fossils, 10: 433 p.

Nessov, L. A. (1984): Pterosaurs and birds of the late Cretaceous of Central Asia. Palaeontologische Zeitschrift, 1: 47-57.

Newton, E. T. (1888): On the skull, brain, and auditory organ of new species of pterosaurian (Scaphognathus purdoni), from the Upper Lias near Whitby, Yorkshire. Philosophical Transactions of the Royal Society, B, 79: 503-537, pls 77-78. http://dx.doi. org/10.1098/rstb.1888.0019

Nopcsa, F. (1928): The genera of reptiles. Palaeobiologica, 1: 163-188.

Olson, S. L. (1985): The fossil record of birds. In Farner, D. S. King, J. R,. Parkes, K. C. (eds.). Avian Biology, Vol. 8. Academic Press, New York: 79-238.

Owen, R. (1870): Fossil Reptilia of the Liassic formations. Supplement 3, Plesiosaurus, Dimorphodon and Ichthyosaurus. Palaeontographical Society Monograph. Pterosauria: 41-81, pls. XVII-XX.

Owen, R. (1874): Fossil Reptilia of the Mesozoic formations. Monograph on the Order Pterosauria. Palaeontographical Society Monograph: 1-14, pls. 1-2.

Patterson, C. (1966): British Wealden sharks. Bulletin of the British Museum (Natural History), Series Zoology, 11: 281-350.

Paul, G. S. (2008): A revised taxonomy of the iguanodont dinosaur genera and species. Cretaceous Research, 29: 192-216. http:// dx.doi.org/10.1016/j.cretres.2007.04.009

Plieninger, F. (1901): Beiträge zur kenntnis der flugsaurier. $\mathrm{Pa}$ läontographica, 48: 65-90.

Radley, J. (1994): Stratigraphy, palaeontology and palaeoenvironment of the Wessex Formation (Wealden Group, Lower Cretaceous) at Yaverland, Isle of Wight. Proceedings of the Ge- 
ologists'Association, 105: 199-208. http://dx.doi.org/10.1016/ $\underline{\text { S0016-7878(08)80119-8 }}$

Robinson, S. A., Hesselbo, S. P. (2004): Fossil-wood carbonisotope stratigraphy of the non-marine Wealden Group (Lower Cretaceous, southern England). Journal of the Geological Society of London, 161: 133-145. http://dx.doi.org/10.1144/0016764903-004

Ruiz-Omeñaca, J. I., Canudo, J. I., Cuenca- Bescós, G. (1998): Primeros restos de reptiles voladores (Pterosauria: Pterodactyloidea) en el Barremiense superior (Cretácico inferior) de Vallipón (Castellote, Teruel). Mas de les Matas, 17: 225-249.

Sánchez-Hernández, B., Benton, M. J., Naish, D. (2007): Dinosaurs and other fossil vertebrates from the Late Jurassic and Early Cretaceous of the Galve area, NE Spain. Palaeogeography, Palaeoclimatology, Palaeoecology, 249: 180-215. http:// dx.doi.org/10.1016/j.palaeo.2007.01.009

Scotese, C. R. (2002): Palaeomap Project. World Wide Web resource: http://www.scotese.com.

Seeley, H. G. (1870): The Ornithosauria: an elementary study of the bones of pterodactyls, made from fossil remains found in the Cambridge Upper Greensand, and arranged in the Woodwardian Museum of the University of Cambridge. Deighton, Bell and Company, Cambridge: xii $+135 \mathrm{p}$.

Seeley, H. G. (1891): The ornithosaurian pelvis. Annals and Magazine of Natural History, 6 (7): 237-255.

Seeley, H. G. (1901): Dragons of the Air. An Account of extinct Flying Reptiles. Methuen, London: xiii $+239 \mathrm{p}$.

Steel, L., Martill, D. M., Unwin, D. M. (2005): A new pterodactyloid pterosaur from the Wessex Formation (Lower Cretaceous) of the Isle of Wight. Cretaceous Research, 26: 686-698. http:// dx.doi.org/10.1016/j.cretres.2005.03.005

Stewart, D. J. (1978): The Sedimentology and Palaeoenvironment of the Wealden Group of the Isle of Wight, Southern England. Unpublished Ph.D. thesis, University of Portsmouth, 346 p. + appendices.

Stewart, D. J. (1981a): A field guide to the Wealden Group of the Hastings area and the Isle of Wight. In: Elliott T. (ed.), Field Guides to Modern and Ancient Fluvial Systems in Britain and Spain. International Fluvial Conference, Department of Geology, University of Keele: 3.1-3.32.

Stewart, D. J. (1981b): A meander belt sandstone from the Lower Cretaceous Wealden Group of southern England. Sedimentology, 28: 1-20. http://dx.doi.org/10.1111/j.1365-3091.1981. tb01658.x

Stewart, D. J. (1983): Possible suspended-load channel deposits from the Wealden Group (Lower Cretaceous) of southern England. In: Collinson, J. D., Lewin, J. (eds.), Modern and Ancient Fluvial Systems. Special Publications. International Association of Sedimentologists 6. Blackwell Scientific Publications, Oxford: 369-384. http://dx.doi.org/10.1002/9781444303773.ch30

Sweetman, S. C. (2004): The first record of velociraptorine dinosaurs (Saurischia, Theropoda) from the Wealden (Early Cretaceous, Barremian) of southern England. Cretaceous Research, 25: 353-364. http://dx.doi.org/10.1016/j.cretres.2004.01.004

Sweetman, S. C. (2006a): A gobiconodontid (Mammalia, Eutriconodonta) from the Early Cretaceous (Barremian) Wessex Formation of the Isle of Wight, southern Britain. Palaeontology, 49: 889-897. http://dx.doi.org/10.1111/j.1475$\underline{\text { 4983.2006.00564.X }}$
Sweetman, S. C. (2006b): The tetrapod microbiota of the Wessex Formation (Lower Cretaceous, Barremian) of the Isle of Wight, UK. In: Barrett, P. M. Evans, S. E. (eds.), Ninth international symposium on Mesozoic terrestrial ecosystems and biota, abstracts and proceedings. The Natural History Museum, London: 127-129.

Sweetman, S. C. (2007): Aspects of the microvertebrate fauna of the Early Cretaceous (Barremian) Wessex Formation of the Isle of Wight, southern England. Unpublished $\mathrm{PhD}$ thesis, University of Portsmouth: $363 \mathrm{p}$. + appendices.

Sweetman, S. C. (2008): A spalacolestine spalacotheriid (Mammalia, Trechnotheria) from the Early Cretaceous (Barremian) of southern England and its bearing on spalacotheriid evolution. Palaeontology, 51: 1367-1385. http://dx.doi.org/10.1111/ j.1475-4983.2008.00816.x

Sweetman, S. C. (2009a): A new species of the plagiaulacoid multituberculate mammal Eobaatar from the Early Cretaceous of southern Britain. Acta Palaeontologica Polonica, 54: 373-384. http://dx.doi.org/10.4202/app.2008.0003

Sweetman, S. C. (2009b): The palaeoecology and preservation of a remarkable terrestrial vertebrate assemblage from the Barremian (Early Cretaceous) of southern Britain. In: Buscalioni, Á, D., Martínez, M. F. (eds.), Tenth international symposium on Mesozoic terrestrial ecosystems and biota, abstracts. Universidad Autónoma de Madrid: 207-209.

Sweetman, S. C., Insole, A. N. (2010): The plant debris beds of the Early Cretaceous (Barremian) Wessex Formation of the Isle of Wight, southern England: their genesis and palaeontological significance. Palaeogeography, Palaeoclimatology, Palaeoecology, 292: 409-424. http://dx.doi.org/10.1016/j.palaeo.2010.03.055

Sweetman, S. C., Underwood, C. J. (2006): A neoselachian shark from the non-marine Wessex Formation (Wealden Group: Early Cretaceous, Barremian) of the Isle of Wight, southern England. Palaeontology, 49: 457-465. http://dx.doi.org/10.1111/j.14754983.2006.00549.x

Unwin, D. M. (1992): The phylogeny of the Pterosauria. Journal of Vertebrate Paleontology, 12, (supplement to No. 3): 57A.

Unwin, D. M. (1995): Preliminary results of a phylogenetic analysis of the Pterosauria (Diapsida: Archosauria). In: Sixth Symposium on Mesozoic terrestrial Ecosystems and Biota, Short Papers, China Ocean Press, Beijing: 69-72.

Unwin, D. M. (2003): On the phylogeny and evolutionary history of pterosaurs. In: Buffetaut, E., Mazin, J.-M. (eds.), Evolution and palaeobiology of pterosaurs. Geological Society, London, Special Publications, 217: 139-190. http://dx.doi.org/10.1144/ GSL.SP.2003.217.01.11

Unwin, D. M., Martill, D. M. (2007): Pterosaurs of the Crato Formation. In: Martill, D. M., Bechly, G., Loveridge, R. F. (eds.), The Crato fossil beds of Brazil: window into an ancient world. Cambridge University Press, Cambridge: 475-524. http:// dx.doi.org/10.1017/CBO9780511535512.018

Vila Nova, B. C., Sayão, J. M. 2009. Redescrição e posição filogenetica de Cearadactylus atrox Leonardi e Borgamanero, 1985 (Reptilia, Pterosauria). In: Abstracts, Paleo 2000: Reuniao annual regional da Sociedade Brasileira de Paleontologia, Crato, Brazil, 2009: 29.

Vullo, R., Buscalioni, A. D., Marugán- Lobón, J., Moratalla, J. J. (2009a): First pterosaur remains from the Early Creta- 
ceous Lagerstätte of Las Hoyas, Spain: palaeoecological significance. Geological Magazine, 146: 931-936. http://dx.doi. org/10.1017/S0016756809990525

Vullo, R., Marugán-Lobón, J., Buscalioni, A. D., Moratalla, J. J. (2009b): The first tapejarid pterosaur from Europe. Journal of Vertebrate Paleontology, 29, (supplement to No. 3): 196A197A.

Wang, L., Campos, D. A., Zhou, Z. H., Kellner, A. W. A. (2008): A primitive istiodactylid pterosaur (Pterodactyloidea) from the Jiufotang Formation (Early Cretaceous), northeast China. Zootaxa, 1813: 1-18.

Wang, L., Kellner, A. W. A., Zhou, Z. H., Campos, D. A. (2005): Pterosaur diversity and faunal turnover in Cretaceous terrestrial ecosystems in China. Nature, 437: 875-879. http://dx.doi. org/10.1038/nature 03982

Wang, L., Kellner, A. W. A., Zhou, Z. H., Campos, D.A. (2007): A new pterosaur (Ctenochasmatidae, Archaeopterodactyloidea) from the Lower Cretaceous Yixian Formation of China. Cretaceous Research, 28: 245-260. http://dx.doi.org/10.1016/j. cretres.2006.08.004

Wang, L., Li, L., Duan, Y., Cheng, S. L. (2006): A new istiodactylid pterosaur from western Lioaning. Geological Bulletin of China, 25: 737-740.
Wang, X., Lü, J. (2001): Discovery of a pterodactylid pterosaur from the Yixian Formation of western Liaoning, China. Chinese Science Bulletin 46: 1112-17. http://dx.doi.org/10.1007/ BF02900633

Weishampel, D., Barrett, P., Coria, R., Loeuff, J., Xu, X., Zhao, X., Sahni, A., Gomani, E., Noto, C. (2004): Dinosaur distribution. In: Weishampel, D., Dodson, P., Osmolska, H. (eds.), The Dinosauria. University of California Press, Berkeley: 517-613.

Wellnhofer, P. (1970): Die Pterodactyloidea (Pterosauria) der Oberjura-Plattenkalke Süddeutschlands. Abhandlungen der Bayerischen Akademie der Wissenschaftten, Neue Folge, 141: 1-133.

Wellnhofer, P. (1991): The illustrated encyclopedia of pterosaurs. Crescent Books, New York: 192 p.

White, H. J. O. (1921): A short account of the geology of the Isle of Wight. Memoirs of the Geological Survey of the United Kingdom. HMSO, London, $219 \mathrm{p}$.

Witton, M., Martill, D. M., Green, M. (2009): On pterodactyloid diversity in the British Wealden (Lower Cretaceous) and a reappraisal of "Palaeornis cliftii" Mantell, 1844. Cretaceous Research, 30: 676-686. http://dx.doi.org/10.1016/j.cretres.2008.12.004

Woodward, A.S. (1889): Catalogue of the fossil fishes in the British Museum. Part 1. British Museum (Natural History), London: $474 \mathrm{p}$. 